\title{
Growing Minds: The Effects of a One-year School Garden Program on Six Constructs of Life Skills of Elementary School Children
}

\author{
Carolyn W. Robinson ${ }^{1}$ and Jayne M. Zajicek ${ }^{2}$
}

\begin{abstract}
ADDITIONAL INDEX WORDs. teamwork skills, self-understanding, leadership, decision-making skills, communication, volunteerism

Summary. The goal of this study was to assess changes in the life skill development of elementary school students participating in a 1-year school garden program. The Life Skills Inventory included statements for six constructs of life skills including teamwork, self-understanding, leadership, decision making skills, communication skills, and volunteerism. The students were divided into two treatment groups, an experimental group that participated in the garden program and a control group that did not participate in the school garden program. Students in the control group had significantly higher overall life skills scores on the pretest compared to students participating in the garden program but the scores were no longer significantly different between the groups on the posttest scores at the end of the program. In addition, there were no significant differences in the control group's pretest scores compared to their posttest scores. However, the students in the experimental group did significantly increase their overall life skills scores by $\mathbf{1 . 5}$ points after participating in the garden program. Two internal life skill scales were positively influenced by the garden program; "working with groups" and "self understanding."
\end{abstract}

$\mathrm{C}$ hildren have many obstacles to overcome in today's society. One of those obstacles is childhood violence which is extremely evident by the violent and morally offensive crimes that are common in newspapers around the world. In 1996, in the United States, juveniles committed $31 \%$ of all crimes; however, juveniles only account for $14 \%$ of the total population (Snyder, 1997). According to the "Indicators of School Crime and Safety: 2002" (DeVoe et al., 2003 ) report conducted by the U.S. Department of Justice, some problem behaviors are on the increase. In 2001, $8 \%$ of students reported being bullied, up from $5 \%$ in 1999 . The number of children that were threatened or injured with a weapon on a school campus remained at $7 \%$ to $9 \%$ in 2001 (DeVoe et al., 2003). Because aggressive children very often become adolescent and adult offenders (Robins, 1983), effective intervention programs are extremely important. It is critical that children receive the social skills needed so that

Acknowledgements: The authors express appreciation for the financial support of the Kellogg Foundation.

${ }^{1}$ Assistant Professor, Department of Agricultural Sciences, Sam Houston State University, Huntsville, TX 77340 .

${ }^{2}$ Professor, Department of Horticultural Sciences, Texas A\&M University, College Station, TX 77843-2133. childhood violence and delinquency problems do not continue to grow. School garden programs are one such place to effectively teach life skills.

Social competence can be defined as the ability of a child to successfully and appropriately select and achieve their interpersonal goals (Guralnick, 1990). Social skills such as interpersonal, communication, anger control, and stress management skills lead to social competence (Cowen, 1991); and being able to appropriately apply these social skills implies that a child has a good social competence (Hundert, 1995). Research has shown that there is a very strong relationship between child-rearing practices and all aspects of a child's adjustment including academic achievement and interpersonal skill development (Rickel and Becker, 1997). The breakdown of traditional families and values has been cited as a major contributor to the weak social and moral development of our children (Zigler et al., 1992).

Children spend an average of $40 \mathrm{~h}$ per week in school and school programs. That is approximately $41 \%$ of their week if you consider them to have a 14-h day. Therefore, schools and school-based programs play a very important role in the socialization of children (Rickel and Becker, 1997).
While life skills development begins before age 5 years (Gardner, 1987), it is influenced all throughout life. School garden programs have the potential to be an effective way to incorporate the various components of life skills with the hands-on activities that a child needs in order to gain and retain these skills throughout life. Gardens offer a place to learn delayed gratification, independence, and motivation (Alexander et al., 1995). Allowing children to experience success in a garden setting gives them the feeling of being valued and a sense of belonging (Barker, 1992). The purpose of this study was to assess changes in the life skill development of elementary school students participating in a l-year school garden program.

\section{Materials and methods}

Instrumentation. The instrument developed for this study was the Youth Life Skills Inventory (YLSI), an adaptation of an adult leadership survey called the Leadership Skills Inventory (LSI) (Townsend and Carter, 1983) and the 4-H National Youth Assessment survey (Peterson et al., 2001). The YLSI included 32 adapted questions from the original surveys that were based on six internal scales: working with groups, understanding self, communicating, making decisions, leadership, and volunteerism. The responses for the LSI were based on a five-point Likert-type scale. In order to make the survey simple for children, the YLSI used a three-point Likert-type scale. The three possible responses to each question and the points associated with each response included: $1=$ yes, $2=$ maybe, and $3=$ no. The wording of the statements used from the LSI and the 4-H National Youth Assessment surveys were changed based on the advice of Dr. Michael Ash, a child development psychologist at Texas A\&M University (M. Ash, personal communication). The statements were modified only to the extent that a child at the third grade reading level would be able to understand and respond.

A pilot test was conducted during the spring semester 2000 with approximately 150 third, fourth, and fifth grade students in the Dallas/Fort Worth, Texas, area. Based on the results of the pilot test, two of the 32 statements were changed to be clearer and more personally applicable to the student. The final version of the YLSI 
Table 1. Internal scales and statements of the Youth Life Skills Inventory.

\begin{tabular}{|c|c|c|}
\hline Scale & $\begin{array}{c}\text { Item } \\
\text { no. }\end{array}$ & Statement \\
\hline \multirow{5}{*}{$\begin{array}{l}\text { Working with } \\
\text { groups }\end{array}$} & 1 & I can work with other people. \\
\hline & 2 & I can work well in a group. \\
\hline & 11 & I think what other people want to say is important. \\
\hline & 14 & When I am in a group, I do what I am supposed to do. \\
\hline & 24 & I think that all people in a group should help in doing a job. \\
\hline \multirow{7}{*}{$\begin{array}{l}\text { Understanding } \\
\text { self }\end{array}$} & 3 & If I do something good, I am proud of myself. \\
\hline & 5 & $\begin{array}{l}\text { If I do something wrong, it's ok to blame it on someone } \\
\text { else. }\end{array}$ \\
\hline & 21 & I think I am a good person. \\
\hline & 29 & I can make my own decisions. \\
\hline & 30 & I can do things on my own. \\
\hline & 31 & I like to do what everyone else is doing. \\
\hline & 32 & I try very hard to do my best. \\
\hline \multirow[t]{4}{*}{ Communicating } & 8 & $\begin{array}{l}\text { When other people want to say something, I listen to what } \\
\text { they want to say. }\end{array}$ \\
\hline & 19 & I am a good listener. \\
\hline & 20 & When I say something, people understand me. \\
\hline & 25 & I am good at following directions. \\
\hline \multirow[t]{5}{*}{ Making decisions } & 7 & $\begin{array}{l}\text { Before I decide on something, I think about what my } \\
\text { choices are. }\end{array}$ \\
\hline & 16 & $\begin{array}{l}\text { When I try to decide what to do, I think about things that } \\
\text { have happened to me before. }\end{array}$ \\
\hline & 18 & $\begin{array}{l}\text { When I try to decide what to do, I ask other people what } \\
\text { they think I should do. }\end{array}$ \\
\hline & 27 & $\begin{array}{l}\text { When I try to decide what to do, I think about what } \\
\text { good things and bad things could happen. }\end{array}$ \\
\hline & 28 & $\begin{array}{l}\text { It is a good idea to have plans in order to get a job } \\
\text { done. }\end{array}$ \\
\hline \multirow[t]{5}{*}{ Leadership } & 6 & There are some things I can show other people how to do. \\
\hline & 12 & Other kids that I know admire me. \\
\hline & 13 & $\begin{array}{l}\text { If I am the leader of a group, I can bring up things that we } \\
\text { need to talk about. }\end{array}$ \\
\hline & 17 & I like being the leader of a group. \\
\hline & 26 & I am good at being a group leader. \\
\hline \multirow[t]{6}{*}{ Volunteerism } & 4 & I think that I should help other people. \\
\hline & 9 & I can help other in important ways. \\
\hline & 10 & I have done things to make life better for others. \\
\hline & 15 & I have learned ways to help people in my community. \\
\hline & 22 & I think that helping other people is important. \\
\hline & 23 & I care about my school. \\
\hline
\end{tabular}

${ }^{2}$ The Youth Life Skills Inventory was an adaptation of the Leadership Skills Inventory (Townsend and Carter, 1983 ) and the 4-H National Youth Assessment survey (Peterson et al., 2001).

is included in Table 1. Also included, as part of the survey, was a demographic section which included questions about gender, ethnicity and grade.

SAMPLE. The sample for this study included classes of third, fourth, and fifth grade students in five schools in the Fort Worth Independent School District in northern Texas, and seven schools in the Temple Independent School District in central Texas during the 2000-01 school year. Teachers from each of the schools within the school districts volunteered their classes to participate in the study. The final sample consisted of a total of 281 students with 190 students in the experimental group, and 91 students in the control group (Table 2).

GARDEN PROGRAM CURRICULUM AND TEACHER TRAINING. Schools participating in the school garden program received copies of a school garden curriculum including youth handbooks for each student participating, and teacher/leader guides for each teacher participating [Texas Agricultural Extension Service (TAEX), 1999a, 1999b]. The garden curriculum is based on a similar adult garden curriculum conducted by state extension agencies throughout the U.S., and
Table 2. Sample demographics: Grade level of experimental and control participants in the life skills development study.

\begin{tabular}{lcc}
\hline Grade level & N & $\begin{array}{c}\text { Proportion } \\
\text { of total } \\
\text { population } \\
(\%)\end{array}$ \\
\hline 3 & 84 & 29 \\
4 & 56 & 20 \\
5 & 50 & 17 \\
Experimental & & \\
\cline { 2 - 3 }$\quad$ subtotal & 190 & 66 \\
3 & 38 & 13 \\
4 & 31 & 11 \\
5 & 22 & 8 \\
Control $\quad$ subtotal & 91 & 32 \\
\hline Total population & 287 & 100 \\
\hline
\end{tabular}

is intended to educate youth about horticulture, health, nutrition, environmental science, and leadership. The objectives of this gardening program include: to develop leadership and life skills; to identify community needs and volunteer service opportunities; to enhance positive youth development through peer teaching and cross-generation mentoring; to improve quality of life through horticultural projects and to increase the availability of horticultural and environmental education for youth (TAEX, 1999a, 1999b). The curriculum is divided into levels targeting different age groups. Level I of the program was used for this study and is targeted to third through fifth grade students.

Experimental groups received the curriculum materials after the pretest was given and prior to initiating gardening activities. Control groups received curriculum materials at the end of the school year, following the conclusion of the study to compensate them for participating in the study. A full-day teacher training program was held with the participating school districts at the beginning of the 2000-01 school year. The teacher training program was coordinated and run by TAEX employees who specialize in the garden curriculum program, as well as graduate students involved in the Growing Minds research program at Texas A\&M University Department of Horticultural Sciences. The training session included a program orientation session, a curriculum overview session, and multiple opportunities 
to trial activities from the curriculum. All teachers in the two districts were eligible and encouraged to participate. Those teachers who were unable to attend the training session received materials and training information from other teachers that did attend the training as well as individual meetings with county extension staff and the researchers. It is not felt that any bias was introduced based on attending or not attending training as the only difference in information supplied was the practice on approximately five of the 96 activities that they were to complete. Teachers volunteering their classes for participation in the experimental group were asked to complete 44 group activities ( 1 for each of the 44 learning concepts), 44 individual activities ( 1 for each of the 44 learning concepts) and eight community service activities ( 1 for each of the 8 chapters) into their curriculum over the course of the school year. The control of the frequency and timing of the activities was given to the teachers.

Data collection. The Texas A\&M University Institutional Review Board approved the study Oct. 1999 prior to the pilot study. Teachers administered pretests in Aug. 2000 and posttests in May 2001. Teachers administered all exams based on the exam administration criteria for the school district. Tests were coded for student confidentiality and distributed by school faculty to the students during regular school hours. The researcher collected the completed tests from each site.

The demographic section and the YSLI of each survey were scanned using Remark Office (OMR 4.0; Principia Products, Paoli, Pa.). The data were then analyzed using SPSS (version 10.0 for Windows95; SPSS, Chicago). Paired samples $t$ tests for independent and paired samples analyses were used to assess the results of the surveys. Additionally, comparisons of demographic information were accomplished using analysis of variance tests with pretests acting as covariates.

\section{Results and discussion}

Cronbach's alpha reliability test showed the YLSI instrument to have high internal consistency with a reliability of 0.87 .

EXPERIMENTAL VS. CONTROL GROUP. The students in the control group had higher overall life skill scores on their pretests than did the experimental group. A $t$ test for independent samples analyses indicated that students in the control group scored significantly higher (2.78 points) than the experimental group on the pretest (Table 3 ). It is unclear why the control students scored higher than the experimental groups. The control schools were evenly distributed in both geographic areas of study. On the posttests, these differences were no longer significant indicating that the students in the experimental group (those who participated in the gardening program) had similar overall life skill scores compared to those in the control group (Table 3).

Pretest vs. Postrest. The $t$ test for paired samples analyses indicated no differences between pretest and posttest scores of the control students, however, there were statistically significant difference between pretest and posttest scores of students who participated in the garden program (Table 4). The $\mathrm{N}$ of these groups is lower because only those students with both a pretest and posttest could be used. The experimental group had significantly higher overall life skill scores on the posttest with an improvement of 1.5 points compared to their pretest scores. Analyses of variance tests were used to analyze the differences between grade, gender and ethnicity on overall life skills posttests scores. Pretest scores were used as covariates to account for any influence the pretest may have had on the posttest scores. The analysis for grade, gender and ethnicity showed no significant bearing on the overall life skills posttest scores. Due to the statistical increase in scores of the students who participated in the garden program, it would appear that this program had a positive influence on the students' overall life skills development regardless of age, gender, or ethnicity. Other researchers have also reported that students who are involved in structured organizations and/or activities, including gardening, have better leadership skills and interpersonal relationship skills (Cox, 1988; Waliczek et al., 2001).

LIFE SKILLS INTERNAL SCALES. In order to detect where specific differ-

Table 3. Comparison of the pretest scores of the experimental group to the pretests scores of the control group; and comparison of the posttest scores of the experimental group to the posttest scores of the control group participating in the life skills development study. ${ }^{\mathrm{z}}$

\begin{tabular}{|c|c|c|c|c|c|c|c|}
\hline $\begin{array}{l}\text { Test } \\
\text { variable }\end{array}$ & Treatment & $\mathbf{N}$ & $\begin{array}{l}\text { Mean } \\
\text { score }^{y}\end{array}$ & SD & df & $t$ & $\begin{array}{c}P \\
(\text { two-tailed })^{x}\end{array}$ \\
\hline \multirow[t]{2}{*}{ Pretest } & Experimental & 147 & 83.02 & 7.95 & 20 & \multirow[b]{2}{*}{-2.43} & \multirow[b]{2}{*}{$0.016^{*}$} \\
\hline & Control & 60 & 85.80 & 6.14 & 5 & & \\
\hline \multirow[t]{2}{*}{ Posttest } & Experimental & 153 & 84.51 & 7.81 & 22 & \multirow{2}{*}{-1.93} & \multirow{2}{*}{0.055} \\
\hline & Control & 76 & 86.49 & 6.19 & 7 & & \\
\hline
\end{tabular}

${ }^{2}$ Comparisons were made using $t$ tests for independent samples.

y Possible scores ranged from 32 to 96

${ }^{x}$ Equal variances assumed.

*Significant at $P \leq 0.05$.

Table 4. Comparisons of the pretest scores of the experimental group to the posttest scores of the experimental group; and comparisons of the pretest scores of the control group to the posttest scores of the control group participating in the life skills development garden program. ${ }^{\mathrm{z}}$

\begin{tabular}{|c|c|c|c|c|c|c|c|}
\hline Treatment & $\begin{array}{c}\text { Test } \\
\text { variable }\end{array}$ & $\mathbf{N}$ & $\begin{array}{l}\text { Mean } \\
\text { score }^{y}\end{array}$ & SD & df & $t$ & $\begin{array}{c}P \\
(\text { two-tailed })^{\mathrm{x}}\end{array}$ \\
\hline Experimental & Pretest & 110 & 83.60 & 6.39 & \multirow[b]{2}{*}{109} & \multirow[b]{2}{*}{-2.40} & \multirow[b]{2}{*}{$0.018^{*}$} \\
\hline \multirow{3}{*}{ Control } & Posttest & 110 & 85.10 & 6.46 & & & \\
\hline & Pretest & 45 & 86.96 & 4.64 & \multirow[b]{2}{*}{44} & \multirow[b]{2}{*}{-0.062} & \multirow[b]{2}{*}{0.951} \\
\hline & Posttest & 45 & 87.00 & 6.15 & & & \\
\hline
\end{tabular}

${ }^{\mathrm{z}}$ Comparisons were made using $t$ tests for independent samples.

y Possible scores ranged from 32 to 96.

${ }^{x}$ Equal variances assumed

"Significant at $P \leq 0.05$. 
Table 5. Comparisons of pretest life skill construct scores to the posttest life skill construct scores of the experimental group participating in the life skills development garden program. ${ }^{2}$

\begin{tabular}{|c|c|c|c|c|c|c|c|}
\hline $\begin{array}{l}\text { Life skill } \\
\text { construct }\end{array}$ & $\begin{array}{c}\text { Test } \\
\text { variable }\end{array}$ & $\mathbf{N}$ & $\begin{array}{l}\text { Mean } \\
\text { score }^{\mathrm{y}}\end{array}$ & SD & df & $t$ & $\begin{array}{c}P \\
(\text { two-tailed })^{\mathrm{x}}\end{array}$ \\
\hline \multirow{2}{*}{$\begin{array}{l}\text { Working with } \\
\text { groups }^{\mathrm{y}}\end{array}$} & Pretest & 110 & 13.33 & 1.74 & \multirow{2}{*}{109} & \multirow{2}{*}{-3.85} & \multirow{2}{*}{$0.000^{*}$} \\
\hline & Posttest & 110 & 14.09 & 1.41 & & & \\
\hline \multirow{2}{*}{$\begin{array}{l}\text { Self- } \\
\text { understanding }\end{array}$} & Pretest & 110 & 16.78 & 1.96 & \multirow{2}{*}{109} & \multirow{2}{*}{-5.56} & \multirow{2}{*}{$0.000^{*}$} \\
\hline & Posttest & 110 & 18.02 & 1.76 & & & \\
\hline \multirow[t]{2}{*}{ Leadership $^{w}$} & Pretest & 110 & 12.62 & 2.05 & \multirow[b]{2}{*}{109} & \multirow[b]{2}{*}{-0.041} & \multirow[b]{2}{*}{0.968} \\
\hline & Posttest & 110 & 12.63 & 1.85 & & & \\
\hline \multirow{2}{*}{$\begin{array}{l}\text { Decision- } \\
\text { making }^{\mathrm{v}}\end{array}$} & Pretest & 110 & 13.71 & 1.64 & \multirow{2}{*}{109} & \multirow{2}{*}{-0.047} & \multirow{2}{*}{0.962} \\
\hline & Posttest & 110 & 13.72 & 1.44 & & & \\
\hline \multirow[t]{2}{*}{ Communication $^{\mathrm{u}}$} & Pretest & 110 & 10.59 & 1.55 & \multirow[b]{2}{*}{109} & \multirow[b]{2}{*}{1.197} & \multirow[b]{2}{*}{0.234} \\
\hline & Posttest & 110 & 10.42 & 1.46 & & & \\
\hline \multirow[t]{2}{*}{ Volunteerism $^{t}$} & Pretest & 110 & 16.57 & 1.77 & \multirow{2}{*}{109} & \multirow{2}{*}{1.740} & \multirow{2}{*}{0.085} \\
\hline & Posttest & 110 & 16.23 & 2.08 & & & \\
\hline
\end{tabular}

${ }^{2}$ Comparisons were made using $t$ tests for independent samples.

yossible scores ranged from 5 to 15 .

xossible scores ranged from 7 to 21 .

"Possible scores ranged from 5 to 15 .

"Possible scores ranged from 5 to 15 .

"Possible scores ranged from 4 to 12 .

Possible scores ranged from 6 to 18 .

* Significant at $P \leq 0.05$.

ences were occurring within the experimental group, additional analyses were conducted.

WORKING WITH GROUPS. A $t$ test for paired samples analysis was conducted to test the statistical difference of the means between the pretest and posttest scores of the experimental group. Significant differences were found between pretest and posttest "working with groups" scores of students participating in the garden program, with a positive increase of 0.76 points (Table 5 ). Five questions made up the "working with groups" internal scale, including numbers 1,2 , 11, 14 and 24 (Table 1). The garden program included three types of activities in which students participated in including: individual, group, and community service activities. It is possible that having exposure to group activities helped students increase their "working with groups" scores. Strom and Strom (1996) reported that working well with classmates can help improve many other life skill development areas including: problem solving skills, school attitudes, communication skills, appreciation of culturally different peers, and an increased willingness to try new tasks.

Self-understanding. A $t$ test for paired samples analysis indicated a significant improvement in "selfunderstanding" scores on the posttest after students participated in the garden program (Table 5). Seven questions made up the "self-understanding" internal scale including numbers 3 , $5,21,29,30,31$, and 32 (Table 1). An increase of 1.24 points was seen between pretest and posttest scores. Self-esteem is a part of self-understanding (Cosden et al., 1999) and it has long been known that garden programs are a means for increasing self-esteem (Bassett, 1979; Montessori, 1912; Sarver, 1985).

LEADERSHIP, MAKING DECISIONS, COMMUNICATION SKILLS, AND VOLUNTEERISM. Ten questions made up the "leadership," "making decisions," "communication skills," and "volunteerism" internal scales (Table 1). A $t$ test for paired samples analyses indicated no significant differences between pretest and posttest scores of students who participated in the garden program for any of these internal scales (Table 5). The teachers and students participating in the garden program had many activities from which to choose, and it is possible that the activities chosen did not encourage growth in these life skill areas. In addition, many of these variables are extremely complex and are influenced by a variety of factors including family values and social life in addition to academic influences (Pope et al., 1988)

\section{Conclusions}

The youth that participated in the year-long garden program increased their overall life skills as well as improved teamwork skills and self-understanding. These skills are extremely important to ensure socially responsible and productive citizens. Gardens are a place where students can work together, make decisions, manage problems (Pivnick, 1994), and gain a sense of responsibility (Bassett, 1979). The middle childhood period marks a strong growth in social relations (Cole and Cole, 1993) and may be the right time in which to introduce youth to gardening and its benefits. In order to gain self-confidence, children need the opportunity to take on responsibilities, complete tasks, and be successful (Leonetti, 1980). Gardens present tasks and responsibilities and if those are met, then success will follow as well as self-confidence. Students with higher self-esteem participate more in school and social activities, have higher school completion rates, have more self-direction, and generally have higher levels of achievement in life (Beane and Lipka, 1987). School garden programs offer youth opportunities to improve the skills necessary to succeed in all aspects of life.

\section{Literature cited}

Alexander, J., M. North, and D. Hendren. 1995. Master gardener classroom garden project: An evaluation of the benefits to children. Children's Environ. 12(2):256263.

Barker, S.L. 1992. The meaning of a youth gardening program: A naturalistic inquiry. PhD Diss., Indiana Univ., Bloomington.

Bassett, T.J. 1979. Vacant lot cultivation: Community gardening in America, 1893-1978. MS Thesis, Univ. of California, Berkeley. 
Beane, J.A. and R.P. Lipka. 1987. When the kids come first: Enhancing self-esteem. Natl. Middle School Assn., Columbus, Ohio.

Cole, M. and S.R. Cole. 1993. The development of children. Sci. Amer. Books, New York.

Cosden, M., K. Elliott, S. Noble, and E. Kelemen. 1999. Self-understanding and self-esteem in children with learning disabilities. Learning Disability Quar. 22(4):279-290.

Cowen, E.J. 1991. In pursuit of wellness. Amer. Psychologist 46:404-408.

Cox, K.J. 1988. Significant adolescent leadership development experiences identified by established leaders in the United States. PhD Diss., Ohio State Univ., Columbus, Ohio. Diss. Abstr. Intl. 49:1120A.

DeVoe, J.F., K. Peter, P. Kaufman, S.A. Ruddy, A.K. Miller, M. Planty, T.D. Snyder, D.T. Durhart, and M.R. Rand. 2003. Indicators of school crime and safety: 2002. U.S. Depts.Educ. and Justice. NCES 2003009/NCJ 196753. Washington, D.C.

Gardner, J.W. 1987. Leadership development: Leadership papers. Independent Sector, Washington, D.C.

Guralnick, M.J. 1990. Social competence and early intervention. J. Early Intervention 14:3-14.

Hundert, J. 1995. Enhancing social competence in young students. PRO-ED, Austin, Texas.

Leonetti, R. 1980. Self-concept and the school child: How to enhance self-confidence and self-esteem. Philosophical Library, New York.

Montessori, M. 1912. The Montessori method. Schocken, New York.
Peterson, B., Gerhard, G., Hunter, K., Marek, L., Phillips, C., and Titcomb, A. 2001. National 4-H impact study. U.S. Dept. Agr., Washington, D.C.

Pivnick, J. 1994. Sowing a school garden: Reaping an environmental ethic. Green Teacher 38:7-8.

Pope, A.W., S.M. McHale, and W.E. Craighead. 1988. Self-esteem enhancement with children and adolescents. Pergamon Press, New York.

Rickel, A.U. and E. Becker. 1997. Keeping children from harm's way: How national policy affects psychological development. Amer. Psychological Assn., Washington, D.C.

Robins, L. 1983. Continuities and discontinuities in psychiatric disorders of children, p. 195-219. In D.E. Mechanic (ed.). Handbook of health care, and the health professions. Free Press, New York.

Sarver, M. 1985. Agritherapy: Plants as learning partners. Academic Therapy 20(4):389-396.

Snyder, H.N. 1997. Juvenile arrests in 1996: Juvenile Justice Bulletin. U.S. Department of Justice, Office of Juvenile Justice and Delinquency Prevention. Washington, D.C.

Strom, R. and P. Strom. 1996. Student evaluation of social skills. J. Instructional Psychology 23:111-116.

Texas Agricultural Extension Service. 1999a. Junior Master Gardener handbook, Level 1.Agr. Commun., Texas A\&M Univ., College Station.
Texas Agricultural Extension Service. 1999b. Junior Master Gardener teacher /leader guide, Level 1. Agr. Commun., Texas A\&M Univ., College Station.

Townsend, C.D. and R. I. Carter. 1983. The relationship of participation in FFA activities and leadership, citizenship, and cooperation. J. Amer. Assn. Teacher Educ. Agr. 24(1):20-25.

Waliczek, T.M., J.C. Bradley, and J.M. Zajicek. 2001. The effect of gardens on children's interpersonal relationships and attitudes toward school. Hort Technology 11(3):466-468

Zigler, E., C. Taussig, and K. Black. 1992. Early childhood intervention: A promising preventative for juvenile delinquency. Amer. Psychologist 47:997-1006. 